\title{
MEDIA DALAM PEMBERITAAN TANJUNG BALAI ASAHAN (STUDI ANALISIS FRAMING TENTANG KERUSUHAN TANJUNG BALAI ASAHAN DI REPUBLIKA.CO.ID)
}

\author{
Alna Hanana ${ }^{1}$ Arif Mulizar ${ }^{2}$ \\ ${ }^{1}$ Dosen Program Studi Ilmu Komunikasi, Universitas Andalas \\ ${ }^{2}$ Dosen Program Studi Ilmu Komunikasi, Universitas Andalas \\ Email; ${ }^{1}$ alna.hanana@gmail.com
}

\begin{abstract}
Media has the ability to construct reality. One of them is by framing the news done by the media. This research was conducted to find out how Republika.co.id frame the report of SARA issues in Tanjung Balai Asahan Riot, North Sumatera. This research uses qualitative method with framing model analysis by Robert $N$. Entman. The results of this study indicate that Republika.co.id sided with Islam and did not provide news containing opinions from other perspectives. This can be seen from the analysis in four categories, which are the definition of the problem, the approximate source of the problem, the moral judgment of the problem, and the settlement of the problem. The news state that the riots have begun conducive and the cause is a nonMuslim citizen. They also present moral values such as restraint and tolerance, legal and communication solutions.
\end{abstract}

Keywords: media construction, news, riot, framing

\section{PENDAHULUAN}

Indonesia adalah negara beragama, tapi bukan negara agama. Indonesia hadir sebagai negara yang menjadikan agama sebagai salah satu dari lima dasar negara, yakni sila pertama dalam Pancasila yang berbunyi "Ketuhanan Yang Maha Esa". Tidak hanya itu, Dalam pembukaan Undang-Undang Dasar 1945 terdapat pula sebuah pengakuan secara jelas bahwa kemerdekaan Indonesia didapatkan "Atas berkat rahmat Allah Yang Maha Kuasa", kalimat ini semakin menegaskan bahwa Tuhan yang dalam hal ini diturunkan ke konsep penyembahan dalam kegiatan beragama menjadi hal yang memiliki porsi besar di negara ini.

Agama adalah pedoman hidup yang berkaitan dengan hal yang tak bisa terjangkau oleh indera manusia. Sedari awal memang mengandung kekuatan yang cenderung ambivalen: menakjubkan (enrapture) dan menghancurkan (annihilate). Modus beragama yang berhenti sebagai pemujaan eksterioritas formalism peribadatan, tanpa kesanggupan menggali interioritas nilai spiritualitas dan moralitas hanyalah berselancar di permukaan gelombang bahaya (Latif, 2013).

Memasuki era reformasi, seiring berkembangnya kebebasan masyarakat dalam memperoleh dan menyebarkan informasi isu agama semakin mudah diperbincangkan di tengah-tengah masyarakat, baik dari mulut ke mulut, maupun melalui media massa. Isu agama tersebut menjadi salah satu "menu" wajib yang tidak henti-hentinya menjadi perhatian media massa. Segala peristiwa 


\section{Vol. 2 No.1 Agustus 2017}

terkait agama, kelompok agama, ajaran agama, tindakan beragama, terlebih konflik agama tak akan lepas dari sorotan media. Tidak hanya dalam skala makro yaitu dunia yang memiliki banyak kelompok agama, tapi juga dalam konteks mikro yaitu negara, dalam hal ini negara Indonesia.

Republika.co.id menjadi salah satu situs berita yang tak ketinggalan dalam deretan media massa konvergensi yang menyebarkan berbagai macam informasi terkait agama. 29 Juli 2016, menjelang tengah malam, terjadi sebuah kerusuhan yang mengebohkan negeri Indonesia. Enam rumah peribadatan di Tanjung Balai Asahan, Sumatera Utara menjadi korban korban pembakaran oleh sekelompok massa dengan sebuah alasan yaitu agama.

"Ada enam vihara dan kelenteng yang diserang beberapa ratus warga. Namun kebanyakan, pembakarannya dilakukan pada alat-alat persembahyangan, dan bangunannya sendiri tidak terbakar habis," 1

Diduga aksi ini terjadi sebagai reaksi dari kelompok masyarakat beragama Islam, yang tersinggung oleh perilaku salah seorang penganut agama Budha di daerah tersebut. Mereka tersinggung karena warga tersebut tidak menerima berkumandangnya suara azan di sekitar rumahnya.

\footnotetext{
${ }^{1}$ juru bicara Kepolisian daerah Sumatera Utara, Kombes Rina Sari Ginting kepada Ging Ginanjar dari BBC Indonesia.
}

Menjadi menarik bahwa sebenarnya berita atau isu yang didengar oleh masyarakat yang melakukan pembakaran bukanlah informasi yang sudah jelas kebenarannya. Bahkan tidak sedikit dari masyarakat yang ikut serta melakukan pembakaran melakukan aksinya karena informasi yang didapat dari media sosialnya. Menurut McLuhan, media massa adalah perpanjangan alat indera kita. Dengan adanya media massa, kita memeroleh informasi tentang benda, orang, atau tempat yang tidak kita alami secara langsung (Rakhmat, 2012). Betapa pengaruh media mampu menggerakkan massa dengan sangat cepat dan tak terkontrol.

Berita yang terdapat dalam media massa merupakan hasil rekonstruksi. Dalam paradigma konstruksionis, realitas dipandang sebagai hasil konstruksi. Oleh karena itu, konsentrasi analisis pada paradigma ini adalah menemukan bagaimana peristiwa atau realitas tersebut dikonstruksi, dan dengan cara apa konstruksi dibentuk. Dalam penelitian ini, peneliti mencoba membedah realitas pemberitaan tentang Kerusuhan Tanjung Balai Asahan yang dilatarbelakangi oleh konflik agama.

Agar mampu mengupas lebih jelas tentang konstruksi yang dilakukan oleh media, dalam penelitian ini peneliti menjadikan Republika.co.id sebagai subjek penelitian sebagai representasi media online yang memberitakan isu kerusuhan yang terjadi di 


\section{Vol. 2 No.1 Agustus 2017}

Tanjung Balai Asahan. Republika.co.id merupakan media online yang merupakan bagian dari media cetak Republika yang merupakan media massa dengan format koran harian Republika. Media ini terbit perdana pada 4 Januari 1993 dan didukung oleh petinggi-petinggi ICMI (Ikatan Cendikiawan Muslim Indonesia).

Selain berbasis dan berlatar belakang keagamaan, Republika tidak hanya membahas tentang keIslaman, menjadi media moderat yang membahas berbagai isu juga dilakukan Republika. Dalam isu kerusuhan Tanjung Balai Asahan ini, Republika.co.id menjadi perhatian peneliti karena beberapa hal, pertama, dalam satu hari Republika.co.id memuat 21 berita terkait kerusuhan Tanjung Balai Asahan. Dibanding situs-situs berita online lainnya seperti tempo.co (13 berita), kompas.com ( 9 berita), ataupun detik.com (12 berita), Republika.co.id jauh menggungguli jumlah pemberitaannya. Selain itu untuk koran hariannya, Republika menjadikan isu kerusuhan Tanjung Balai Asahan sebagai berita yang diletakkan di halaman pertama selama tiga hari berturut-turut, sejak tanggal 31 Juli hingga 2 Agustus 2016.

\section{METODE}

Penelitian ini menggunakan metode kualitatif dengan paradigm konstruktivis. Analisis yang digunakan adalah analisis framing pada Republika.co.id. Framing adalah suatu pendekatan untuk melihat bagaimana realitas itu dibentuk dan dikontruksi oleh media. Penyajian tersebut dilakukan dengan menekankan bagian tertentu, menonjolkan aspek tertentu, dan membesarkan cara bercerita tertentu dari suatu realitas. Disini, media menyeleksi, menghubungkan, dan menonjolkan peristiwa sehingga makna dari peristiwa lebih mudah diingat oleh khalayak (Eriyanto, 2011)

Beberapa media mungkin memiliki bahan yang sama untuk diberitakan, namun setelah dijadikan tulisan hasilnya tentu akan berbeda. Setiap media memiliki cara pandang masing-masing terhadap suatu isu.Hal ini sesuai dengan dua aspek yang ditekankan dalam penelitian framing. Pertama, memilih fakta atau realitas. Hal ini berhubungan dengan bagian mana yang diliput (dipilih) dan tidak diliput (dibuang). Kedua, menuliskan fakta. Gagasan ini diungkapkan dengan kata, kalimat, dan foto untuk mendukung gagasan (Eriyanto, 2012).

Dalam menghasilkan produk pemberitaan, media massa dipengaruhi oleh berbagai faktor internal dan eksternal. Faktor internal antara lain kebijakan redaksional, kepentingan politik para pengelola media, dan pengaruh para relasi media yang ditunggangi kekuatan politik tertentu. Sedangkan faktor eksternal antara lain tekanan pasar pembaca, sistem politik yang berlaku, dan kekuatankekuatan lainnya. Walaupun media massa harus bersikap netral pada tiap pemberitaan, 


\section{Vol. 2 No.1 Agustus 2017}

hal-hal internal dan eksternal seperti yang telah disebutkan sangat berpengaruh dalam setiap pemberitaan. Faktor internal dan eksternal yang ada di dalam keredaksian juga akan mempengaruhi kerja wartawan di lapangan. Misalnya saja pemilihan sudut pandang atau narasumber akan berpengaruh pada isu sebuah pemberitaan. Media nasional dan lokal juga sudah pasti memiliki faktor internal dan eksternal yang berbeda dalam pemberitaan.

Begitu juga dengan media-media nasional seperti Republika.co.id. Murray Edelman mengatakan bahwa realitas yang sama bisa jadi akan menghasilkan realitas yang berbeda ketika realitas tersebut dibingkai dan dikonstruksi dengan cara yang berbeda (Eriyanto, 2002:155).

Di balik perbedaan yang tampak pada setiap media, sebenarnya ada pesan yang lebih menarik yang ingin disampaikan media kepada khalayak sesuai dengan target sasarannya. Pesan itu disampaikan lewat pemilihan judul, penggunaan bahasa, pemilihan sudut pandang, dan lainnya melibatkan sebuah konstruksi yang telah dianut oleh media massa. Lewat judul, bahasa, dan sudut pandang dapat terlihat bagaimana sebuah media massa menginginkan peristiwa yang terjadi dibentuk dan dikonstruksi. Hal inilah yang menjadi pusat perhatian dan alasan peneliti untuk meneliti pemberitaan melalui metode framing.
Teks berita yang dihadirkan media massa kepada khalayak merupakan sebuah rekonstruksi tertulis mengenai sebuah realitas. Pesan yang hadir di media massa merepresentasikan ideologi media massa yang bersangkutan. Bisa jadi ideologi tersebut merupakan yang dianut oleh media massa tersebut, atau ideologi yang secara dominan berpengaruh dan kemudian diadopsi oleh media tersebut. Ideologi itulah yang menjadi dasar kebijakan redaksional tiap media dan pada akhirnya tercermin dalam pemberitaannya. Ashadi Siregar mengemukakan peristiwa perlu diberitakan paling tidak berdasarkan dua alasan, yaitu untuk memenuhi tujuan politik keredaksian suatu media massa atau memenuhi kebutuhan pembaca (Siregar, 1998:19)

Berbagai hal yang terjadi, fakta, orang, diabstraksikan menjadi peristiwa yang kemudian hadir di hadapan khalayak. Jadi dalam penelitian framing, yang menjadi titik persoalan adalah bagaimana peristiwa atau realitas dikonstruksi oleh media. Lebih spesifik, bagaimana media membingkai peristiwa dalam konstruksi tertentu. Sehingga yang menjadi titik perhatian bukan apakah media memberitakan positif atau negatif, melainkan bagaimana yang dikembangkan oleh media (Eriyanto: 2002, 7).

Dalam pembingkaian (framing) yang dilakukan oleh media ada beberapa faktor yang harus diperhatikan diantaranya adalah 


\section{Vol. 2 No.1 Agustus 2017}

tuntutan teknis seperti keterbatasanketerbatasan kolom dan halaman. Menurut kaidah jurnalistik, peristiwa yang panjang, lebar, dan rumit, "disederhanakan" melalui mekanisme framing fakta-fakta dalam bentuk berita sehingga layak terbit. Pembuatan frame itu sendiri didasarkan pada kepentingan internal maupun eksternal media, baik teknis, ekonomis, politis, atau ideologis. Sehingga pembuatan sebuah wacana tidak saja mengindikasikan adanya kepentingankepentingan itu, tetapi juga bisa mengarahkan: hendak dibawa kemana isu yang diangkat dalam wacana tersebut.

Oleh sebab itu, peneliti tertarik untuk mengetahui bagaimana media dalam mengonstruksi realitas di setiap pemberitaannya. Hal ini bukanlah hal yang bisa kita remehkan begitu saja, betapa media sangat berperan penting dalam berbagai isu yang berkembang di masyarakat. Kita menjadi saksi sejarah sebuah konflik agama yang berakhir dengan sebuah kerusuhan dan diakhiri dengan pembakaran tempat ibadah.

\section{HASIL}

Dari uraian di atas peneliti memiliki sebuah asumsi bahwa Republika memiliki cara pandang tersendiri terhadap isu kerusuhan ini. Dari beberapa judul yang peneliti lihat, Republika.co.id terlihat menggunakan katakata yang cenderung seimbang seperti ketika beberapa judul berita menggunakan kata “provokasi", "kericuhan", dan "kerusuhan", di beberapa judul berita lainnya terdapat kata"damai","terkendali",dan “aman".

Menjadi menarik apabila penelitian ini bisa dilaksanakan dan dikembangkan oleh sebuah institusi pendidikan. Penelitian ini diharapkan menjadi sebuah gambaran dan referensi ilmiah bagi masyarakat, maupun pemerintah atau juga media massa tentang konstruksi realitas yang berupa pembingkaian dari berita-berita dengan isu kerusuhan berlandaskan konflik agama. Indonesia yang multiagama dan mutietnis menurut peneliti sangat rawan terjadi konflik horizontal, butuh sebuah gambaran dan referensi tentang bagaimana konstruksi media tentang isu agama, dalam hal ini isu kerusuhan Tanjung Balai menjadi salah satu contohnya. Oleh sebab itu peneliti berusaha untuk mengupas pembingkaian Republika.co.id dari empat elemen framing Robert Entman yaitu, pendefinisian masalah, penyebab masalah, keputusan moral, dan solusi dari permasalahan.

Dari dua puluh satu (21) berita yang disajikan oleh Republika.co.id peneliti berkesimpulan, Republika.co.id berupaya memberikan informasi pada masyarakat di Indonesia tentang sebuah peristiwa yang terjadi di Negara ini. Kerusuhan berlatar belakang agama dan suku yang terjadi di Tanjung Balai Asahan, Sumatera Utara ini dijelaskan oleh republika.co.id sebagai sebuah 


\section{Vol. 2 No.1 Agustus 2017}

kerusuhan yang sudah mulai kondusif keadaanya.

Hal ini dapat dilihat dari berbagai judul yang disajikan oleh Republika.co.id, sebagai berita pertama yang diturunkan pukul 10.10 WIB, Republika.co.id sadar betul bahwa di media-media TV nasional telah disiarkan bahwa terdapat penjarahan selama kerusuhan dan pembakaran berlangsung di Tanjung Balai Asahan, untuk menguatkan pandangannya bahwa kerusuhan telah selesai dan suasana telah kondusif, judul yang disajikan adalah "Polisi Amankan 7 penjarah dalam Kerusuhan Tanjung Balai”. Dari judul dan isi berita, pembaca dapat menangkap pesan bahwa kerusuhan yang di dalamnya terdapat penjarahan telah berhasil diamankan pihak berwajib.

Dengan framing model Robert $\mathrm{M}$. Entman, ditemukan dari 21 berita yang disajikan Republika.co.id peneliti peroleh kesimpulan, Republika.co.id sedang berusaha mendefinisikan ulang kasus Kerusuhan Tanjung Balai in, menjauhkan kesan horror dan anarkis serta chaos yang terjadi menjadi kondisi yang mulai kondusif dan terkendali.

Definisi masalah bagi Republika.co.id itu ialah; "Kerusuhan di Tanjung Balai Asahan sudah mulai kondusif dan sudah menemukan jalan keluar". Itulah Problem Identification dari Republika.co.id soal Kerusuhan Tanjung Balai Asahan ini.
Sementara yang menjadi penyebab munculnya Kerusuhan ini dapat kita lihat sesuai dengan pemaparan pada bagian hasil penelitian bahwa Republika.co.id menyatakan "adanya seorang dari etnis Tionghoa yang melakukan protes akibat suara azan di masjid" dari pernyataan ini dapat dilihat bahwa penekanan keberatan akan suara azan merupakan masalah utama yang menimbulkan kerusuhan. Tidak hanya itu, pernyataan ini disimpulkan peneliti berdasarkan data yang juga dapat ditemukan pada judul berita pada pukul 10:56 WIB "Rusuh Tanjung Balai diduga dipicu adanya keberatan Volume Azan”. Judul berita ini semakin mengukuhkan bahwa penyebab inilah yang harus diperhatikan khalayak Republika.co.id.

Dari definisi dan penyebab yang diungkapkan, Republika.co.id memutuskan secara moral, bahwa sikap tenggang rasa, saling menghargai, menghormati, tenang dan tidak terburu-buru dalam bersikap serta tidak mudah terprovokasi merupakan nilai-nilai yang harus diresapi oleh masyarakat di lokasi kejadian perkara dan juga masyarakat yang mengikuti perkembangan isu kerusuhan ini. Empat judul berita bahkan focus dengan hal tersebut yakni meminta pada masyarakat agar "tidak terprovokasi, tetap tenang dan tidak termakan isu SARA". Menurut Jamal Husni ,MM. Ketua Lajnah Khusus Ulama, Hizbut Tahrir Indonesia, kehidupan di Indonesia ini kaya akan budaya dan agama,tiap orang 


\section{Vol. 2 No.1 Agustus 2017}

memiliki keyakinan yang berbeda-beda terhadap agamanya masing. Namun, jika sudah menyangkut agama orang akan gampang untuk terpengaruh dan mudah tersulut emosinya jika agamanya dihina. "penting bagi pemerintah untuk memperhatikan aturan terkait pelecehan atau penistaan agama secara lebih tegas" ujarnya.

Terakhir ialah solusi yang ditawarkan oleh Republika.co.id melalui berita-berita yang disajikannya ialah; Karena kerusuhan yang berbau SARA ini terjadi karena kesalahpahaman dan bentuk komunikasi yang tidak baik dari satu individu ke individu lain dan ditanggapi pula dengan ketidakmampuan menahan diri. Maka solusinya adalah untuk kerusuhan dan pembakaran yang merupakan tindak pidana akan diselesaikan melalui proses hokum yang diserahkan pada pihak berwenang, dan solusi untuk mengatasi permasalahan yang mengandung unsur SARA, diselesaikan dengan dialog dan diskusi serta pertemuan antar elemen masyarakat dan pemuka berbagai agama. Sebagai pertimbangan, suatu daerah yang masih memegang tatanan norma dan budaya peran diskusi dan musyawarah sangat penting dan diutamakan. Senada dengan apa yang disampaikan oleh Ketua Badan Musyawarah Kanagarian Ladang Laweh, Alwys Adha. Menurutnya, peran elemen masyarakat dalam membuka ruang-ruang diskusi bagi masyarakat akan mengurangi dan menyelesaikan berbagai konflik yang terjadi, apapun itu sumber konfliknya. "Tapi peran hukum juga sangat dibutuhkan" tambahnya.

Dengan solusi yang ditawarkan itu, diharapakan dapat menjalin kerjasama, dan silaturahmi antar umat beragama sehingga kejadian serupa tidak terulang dan kejadian yang telah terjadi dapat segera diatasi dan dipulihkan keadaanya. Terlihat Republika.co.id sangat ingin solusi ini menjadi inti dari solusi, dari 21 berita yang disajikan semua solusi mengarahkan pembaca untuk memahami bahwa solusi yang ditawarkanlah yang menjadi isu terbaik bagi kepentingan semua. 


\begin{tabular}{|c|c|}
\hline ELEMEN FRAMING YANG DITELITI & HASIL \\
\hline $\begin{array}{l}\text { Republika.co.id mendefinisikan peristiwa } \\
\text { Kerusuhan Tanjung Balai Asahan. }\end{array}$ & $\begin{array}{l}\text { Republika.co.id mendefinisikan bahwa } \\
\text { kerusuhan Tanjung Balai Asahan yang berupa } \\
\text { tindakan anarkis telah mulai kondusif dan } \\
\text { terkendali tidak hanya itu, dalam berita yang } \\
\text { disajikan Republika.co.id juga menyajikan } \\
\text { beberapa pandangan dari pihak-pihak yang } \\
\text { menilai bahwa situasi di Tanjung Balai } \\
\text { adalah konflik sosial yang mudah } \\
\text { diselesaikan. } \\
\text { Dari } 21 \text { berita yang disajikan dalam satu hari } \\
\text { media ini, lebih berita menjelaskan bahwa } \\
\text { situasi keamanan di Tanjung Balai pasca } \\
\text { kerusuhan telah mulai kondusif, tenang } \\
\text { dan sudah ditemukan jalan keluarnya. }\end{array}$ \\
\hline $\begin{array}{l}\text { Republika.co.id memperkirakan penyebab } \\
\text { masalah dalam pemberitaan Kerusuhan } \\
\text { Tanjung BalaiAsahan }\end{array}$ & $\begin{array}{l}\text { Republika.co.id dalam membingkai berita dari } \\
\text { aspek perkiraan masalah kasus ini } \\
\text { memunculkan satu penyebab masalah. dari } 21 \\
\text { berita yang disajikan di dominasi oleh } \\
\text { penyebab yang sama. Penyebab yang } \\
\text { disampaikan dalam Isu besar yakni kerusuhan } \\
\text { Tanjung Balai Asahan adalah " } \text { kerusuhan } \\
\text { tersebut dipicu adanya keberatan dari } \\
\text { seorang warga etnis Tionghoa atas volume } \\
\text { adzan yang dikumandangan di salah satu } \\
\text { masjid. Nada bicara perempuan berinisial M } \\
\text { tersebut saat menegur dinilai kasar dan } \\
\text { menyinggung jamaah di dalam masjid. } \\
\text { Hal ini disampaikan lebih dari setengah berita. } \\
\text { Dengan ini dapat dikatakan bahwa penyebab } \\
\text { maslaah utama hanya satu poin, dan itu adalah } \\
\text { masalah yang disampaikan di atas. }\end{array}$ \\
\hline $\begin{array}{l}\text { Republika.co.id melakukan pilihan moral } \\
\text { dalam pembingkaian Kerusuhan Tanjung } \\
\text { Balai Asahan }\end{array}$ & $\begin{array}{l}\text { Dua puluh satu (21) berita yang dituliskan } \\
\text { oleh Republika.co.id dan dipublish dalam satu } \\
\text { hari lewat kanal nasionalnya memberikan } \\
\text { nilai-nilai moral yang dapat ditangkap oleh } \\
\text { peneliti. } \\
\text { Dari } 21 \text { berita } 17 \text { berita menyampaikan nilai } \\
\text { moral tentang "menahan diri, saling } \\
\text { menghargai, tidak mudah terprovokasi, } \\
\text { saling menghormati, dan toleransi" }\end{array}$ \\
\hline $\begin{array}{l}\text { Republika.co.id menekankan penyelesaian } \\
\text { masalah dalam pemberitaan Kerusuhan } \\
\text { Tanjung BalaiAsahan }\end{array}$ & $\begin{array}{l}\text { Dalam menekankan penyelesaian masalah } \\
\text { Republika.co.id sepertinya tidak ragu dalam } \\
\text { memastikan pembingkaian isu ini. Menurut } \\
\text { peneliti, sesuai dengan pendefinisian masalah } \\
\text { Republika.co.id ingin menunjukkan pada } \\
\text { khalayak bahw aisu ini sudah jelas solusinya, } \\
21 \text { berita yang ditampilkan, seluruhnya } \\
\text { menjelaskan bahwa solusi dari masalah ini } \\
\text { adalah "proses hukum dan dialog atau } \\
\text { diskusi lewat pertemuan antar elemen } \\
\text { masyarakat" }\end{array}$ \\
\hline
\end{tabular}




\section{PEMBAHASAN}

Entman melihat framing dalam dua dimensi besar; seleksi isu dan penekanan atau penonjolan aspek-aspek tertentu dari realitas isu. Seleksi isu terkait dengan proses pemilahan, fakta mana yang akan dimasukkan dalam berita dan fakta mana yang dibuang. Tidak semua bagian dari satu isu ditampilkan, wartawan meilih aspek tertentu dari satu isu.

Sedangkan penonjolan isu ialah proses di mana informasi dibuat mejadi lebih bermakna, lebih menarik, berarti sehingga lebih mudah diingat oleh khalayak. Relitas yang ditonjolkan ini kemudian berkemungkinan lebih besar untuk diperhatikan. Dengan begitu, realitas yang ditonjolkan tersebut mempengaruhi khalayak dalam memahami suatu realitas.

Dari 21 berita bertemakan Kerusuhan Tanjung Balai Asahan yang disajikan dalam kanal Republika.co.id sangat nampak dalam menyeleksi isu. Pertama, Republika.co.id hanya menyajikan fakta yang menjelaskan tentang hal-hal yang mendukung pembingkaiannya terhadap isu kerusuhan ini. Isu yang ditampilkan mengarah pada hal-hal yang menunjukkan bahwa kerusuhan di Tanjung Bali sudah teratasi dan dampaknya sudah tidak ada, suasana sudah kondusif. Mulai dari pemaparan tentang penjarah yang sudah diamankan polisi, situasi Tanjung Balai yang sudah Tenang, Kunjungan-kunjungan penandatanganan kesepakatan damai di Tanjung Balai, serta pandangan-pandangan pihak lain yang menenangkan masyarakat dan menyatakan bahwa keadaan sudah aman dengan kunjungan yang dilakukan.

Kedua, dalam pemilihan narasumber pun, hanya narasumber dari satu sisi. Sumber yang diambil Republika.co.id memang beragam tapi semuanya bersikap netral atau mendukung seleksi isu yang dilakukan, kapolri, ketua DPR, Ketua MPR, ketua PP Muhammadiyah, dan Ketua Tionghoa Bogor. Republika.co.id tidak memberikan ruang bagi narasumber yang mempunyai pendapat tentang keadaan Tanjung Balai, atau sumber lain yang menyalahkan oknum atau membuat isu baru terkait kerusuhan.

Dalam penonjolan isu, Republika.co.id memperlihatkannya secara gamblang. Mulai dari judul dan pengulangan kata di setiap berita. Kata yang sering muncul dalam berita ialah "provokasi" dan "menahan diri", selain itu "toleransi, menghargai dan menghormati" juga muncul di dalam beberapa berita yang disajikan. Jika kita melihat kembali pada setiap bagian berita, bahwa penyebab masalah yakni keberatannya seorang wanita beretnis Tionghoa terhadap volume suara azan.

Hal ini menunjukkan bahwa Republika.co.id ingin menunjukkan pembakaran vihara dan kerusuhan diawali oleh ketidak mampuan seorang wnaita non muslim dalam menjaga toleransi dan menghargai suatu 


\section{Vol. 2 No.1 Agustus 2017}

kegiatan spiritual Islam yakni suara azan. Tidak dijelaskan secara detil bagaimana wanita tersebut menyampaikan protesnya, bahkan tidak dijelaskan juga kerugian, atau dampak pembakaran yang terjadi di beberapa Vihara.

Semua berita yang disajikan ialah hasil konstruksi yang dilakukan oleh Republika.co.id selaku agen konstruksinya. Berita-berita yang disajikan ialah hasil konstruksi kerja para jurnalis Republika.co.id. Karena itu, berita yang disajikan pantaslah bersifat subjektif. Memang tidak ada yang salah dengan itu karena apa yang tersaji merupakan realitas yang dihasilkan dari pemaknaan dari wartawan Republika.co.id. pada dasarnya, memang pemaknaan setiap orang atas suatu realitas bisa berbeda. Pandangan berbeda itu pulalah yang menghasilkan "realitas" yang berbeda.

Dalam mengonstruksi realita mengenai kerusuhan Tanjung Balai ini, Republika.co.id melakukannya melalui empat tahapan. Empat tahapan ini didasarkan pada tahapan membentuk konstruksi sosial media massa yang diungkapkan oleh Burhan Bungin dalam bukunya; Sosiologi Komunikasi. Pertama, tahapan menyiapkan materi konstruksi. Kedua, tahap sebaran konstruksi. Ketiga, tahap pembentukan realitas. Keempat, tahap konfirmasi.

Pada tahap pertama, yakni tahap persiapan materi konstruksi. Pada tahap ini, bermula dari pengangkatan isu Kerusuhan Tanjung Balai Asahan sebagai objek pemberitaan. Setelah itu, menentukan subjek wawancara atau narasumber. Serta pemilihan focus isu yang akan ditonjolkan dan ditekankan pada masalah utama.

Pada tahap pertama pengonstruksian ini, Bungin memasukkan tiga unsur pembangunnya (2008:205); pertama, "keberpihakan media massa kepada kapitalisme". Dalam hal ini, Republika.co.id bisa dilihat, berpihak pada umat muslim. Dilihat dari judul beserta isi berita yang berisikan satu sisi saja juga dari narasumber yang dipilih Republika.co.id untuk menunjang interpretasinya terhadap fakta kerusuhan yang terjadi di Tanjung Balai. Dalam hal ini dapat diketahui bahwa republika.co.id memiliki khalayak mayoritas muslim, sesuai dengan sejarah berdirinya Republika pada tahun 1993 yang dipelopori oleh Ikatan Cendikiawan Muslim Indonesia. Sehingga jelas Republika.co.id tidak ingin menyudutkan muslim dalam pemberitaannya, khalayaknya yang muslim menjadi perhatian khusus bagi Republika untuk terus dijaga sebagai konsumen medianya. Dengan terjaganya konsumen maka akan stabillah viewers situs Republika.co.id, akan banyak muslim yang membagikan beritanya ke muslim lain yang jumlahnya besar di Indonesia.

Unsur kedua ialah "keberpihakan semu kepada masyarakat". Unsur ini tidak 


\section{Vol. 2 No.1 Agustus 2017}

terlalu terlihat pada pemberitaan karena masyrakat yang menjadi khalayak Republika.co.id sangat dibela dan berusaha selalu berada di sisi yang sama.

Kemudian, unsur ketiga ialah "keberpihakan kepada kepentingan umum hanyalah visi”. Untuk unsur ketiga ini, dapat dilihat jika keberpihakan Republika.co.id pada umat muslim. Tidak secara umum. Muslim menjadi pihak yang tidak terlalu bersalah dalam 21 pemberitaannya.

Tahap kedua ialah tahap sebaran konstruksi. Berdasarkan karakteristiknya, media daring periodesasi penerbitannya sangat cepat; bisa harian, bahkan jam. Dalam 21 berita yang disajikan Republika.co.id, sejak pukul 10:10 WIB pada tanggal 30 Juli 2016 hingga pukul 23:35 WIB 30 Juli 2016 frekuensi berita muncul dengan waktu yang berbeda-beda, mulai dari yang tercepat selam 4 menit, hingga terlama selama 2 jam 54 menit . Nilai aktualitas pada Republika.co.id ialah pada isu yang diangkat untuk diberitakan, dalam hal ini ialah Kerusuhan yang baru saja terjadi

Isu agama memang menjadi isu yang mendapatkan banyak perhatian untuk beberapa waktu terakhir ini di Indonesia. Isu ini pun dibahas dari berbagai sisi, namun, mayoritas membawanya menjadi isu politis.

Tahap ketiga ialah tahap pembentukan realitas. Republika.co.id menilai dan menyajikan informasi lewat berita yang di "bombardir" sehari penuh dengan 21 berita, isu yang dilemparkan adalah kerusuhan Tanjung Balai Asahan sudah kondusif, tidak berdampak besar, terkendali, dan banyaknya kunjungan dari pejabat Negara membuktikan bahwa keadaan di sana sudah aman.

Republika.co.id menilai persepsi publik yang mengatakan"kerusuhan disebabkan oleh umat Islam yang anarkis" ialah salah. Pandangan yang menilai Islam adalah agama yang mengajarkan kekerasan dan tidak toleran dijadikan isu yang tidak menarik bagi Republika.co.id, mereka lebih fokus untuk menjabarkan bahwa kerusuhan tersebut telah kondusif dan terjadi karena sikap intoleran penganut agama lain.

Kemudian pada tahap keempat konstruksi, ialah tahap konfirmasi. Bentuk pada tahap ini berupa argumen yang dibangun untuk menopang konstruksi sosial yang dibangun oleh media. Republika.co.id mengontruksi kerusuhan Tanjung Balai Asahan sebagai peristiwa yang besifat spontan dan terjadi karena lompatan emosi dan kesalahpahaman antar warga yang tidak menerima atas perilaku tidak tolerannya seornag non muslim terhadap volume azan. Pembakaran Vihara tidak dibahas terlalu dalam, yang ditekankan adalah kerusuhan sudah dapat dikendalikan, suasana lokasipun sudah kondusif, dan masyarakat diminta menahan diri, dan menjaga sikap toleransi, 


\section{Vol. 2 No.1 Agustus 2017}

saling mengahrgai dan menghormati antar pemeluk dan ajaran agama.

Pernyataan ini didukung oleh kalimatkalimat yang dikeluarkan oleh berbagai narasumber yang kredibel di bidangnya. Statemen yang disampaikan seolah-olah mendukung dan menguatkan pendapat Republika.co.id bahwa keadaan sudah membaik, dan masyarakat diminta lebih toleran dan menahan diri serta tidak mudah diprovokasi.

Untuk menjelaskan proses yang terjadi dalm proses konstruksi tersebut, dapat dilihat dengan menggunakan teori yang dibuat oleh Pamel J. Shoemaker dan Stephen D. Reese, yakni teori Hierarki Pengaruh Isi Media. Teori ini menjelaskan, isi media itu dipengaruhi oleh lima level; pengaruh dari individu pekerja media (individual level), pengaruh dari rutinitas media (media routines level), pengaruh dari organisasi media (organizational level), pengaruh dari luar media (extra media level), dan yang terakhir ialah pengaruh ideologi (ideology level).

Asumsi dari teori ini adalah isi pesan media yang disampaikan kepada khalayak adalah hasil pengaruh dari kebijakan internal organisasi media dan pengaruh dari eksternal media itu sendiri. Pengaruh internal pada konten media sebenarnya berhubungan dengan kepentingan dari pemilik media, individu wartawan sebagai pencari berita, rutinitas organisasi media. Sedangkan faktor eksternal yang berpengaruh pada konten media berhubungan dengan para pengiklan, pemerintah masyarakat, dan lain sebagainya.

Pada level individu, Republika.co.id memberikan kebebasan kepada wartawannya untuk mencari fakta yang ditemukan di lapangan terkait suatu peristiwa. Mereka bebas dan mengolah fakta yang kemudian dibentuk menjadi sebuah berita. Namun, bukan berarti peristiwa yang dikonstruksi oleh wartawan tersebut menjadi sama. Pengaruh-pengaruh seperti latar belakangan pendidikan, orientasi politik, latar belakang agama, dan lainnya ikut andil dalam proses pencarian dan pengolahan fakta di lapangan.

$$
\text { Walaupun demikian, aspek }
$$

kepercayaan dan nilai-nilai tidak terlalu berefek kepada wartawan karena aspek organisasi dan rutinitas media lah yang lebih kuat. Pada tingkat individu, jurnalis dan editor sebagai gatekeepers memainkan peran dalam memilih, mengumpulkan dan mengolah fakta menjadi sebuah berita. Dalam berita ini Republika.co.id menuliskan beritanya dari contributor yang berada di lokasi kejadian. Wartawan mencari fakta di lapangan, kemudian mengolahnya dan menuliskannya menjadi sebuah berita. Setelah itu editor atau redaktur menyeleksi isu dan menjaga agar tulisan para wartawannya tetap sesuai dengan koridor ideologi yang dianutnya. Ideologi yang dimiliki Republika.co.id adalah sebagai media yang berlandaskan nilai-nilai ke-Islaman. 
Level selanjutnya adalah rutinitas organisasi. Proses produksi yang dilakukan Republika.co.id yaitu mulai dari proses pencarian fakta dan data di lapangan, rapat redaksi, penentuan isu, penyuntingan, dan pencetakan. Rutinitas media (media routines) terbentuk oleh tiga unsur yang saling berkaitan, yaitu sumber berita (suppliers), organisasi media (producers), dan audiens (consumers). Ketiga unsur ini saling berhubungan dan berkaitan dan pada akhirnya membentuk rutinitas media dalam membentuk pemberitaan.

Dalam pemberitaan Kerusuhan Tnajung Balai Asahan, rutinitas organisasi turut berpengaruh dalam penenetuan isi. Dari 21 berita yang dijadikan subjek penelitian sumber berita cenderung berasal dari satu sisi saja, yaitu pemerintah. Hal ini menandakan adanya kedekatan antara media dengan pemerintahan yang sedang berjalan. Secara tidak langsung, media ingin menunjukkan bahwa pemerintah memiliki ide yang sama dengan apa yang mereka inginkan.

Level berikutnya yaitu organisasi. Berkaitan dengan level sebelumnya, pada teori hirarki pengaruh, yaitu level individu dan level rutinitas media, level organisasi lebih berpengaruh dibanding kedua level sebelumnya. Hal ini dikarenakan kebijakan terbesar dipegang oleh pemilik media melalui editor pada sebuah media. Jadi penentu kebijakan pada sebuah media dalam menentukan sebuah pemberitaan tetap dipegang oleh pemilik media tersebut.

Pengaruh organisasi ini juga terlihat dari isi berita terkait isu Kerusuhan ini, walaupun pada dasarnya setiap wartawan diberikan kebebasan untuk mencari dan mengembangkan fakta yang ia temukan di lapangan, tetapi ketika hal tersebut bertolak belakang atau tidak sesuai dengan patokan, maka wartawan harus mengalah. Jika wartawan merasa tidak cocok dengan organisasi media, maka wartawan tersebut bisa memilih untuk keluar.

Kebijakan redaksi jelas terlihat pada penentuan arah pemberitaan. Ketika Republika.co.id menentukan bahwa arah pemberitaan adalah agar membingkai isu kerusuhan Tanjung Balai sebagai isu yang sudah mulai kondusif, tidak akan menjadi masalah besar yang berlarut-larut dan disebabkan oleh tidak tolerannya non muslim terhadap muslim tentu telah melalui rapat dan koordinasi yang dilakukan oleh organisasi yang biasa disebut kerdaksian.

Shoemaker dan Reese mengatakan terkadang pemilik sebuah media memiliki afiliasi politik atau pemempin sebuah partai partai politik. Inilah yan memengaruhi pemberitaan sebuah media massa karena berkaitan dengan kepentingan politik pemilik media. Jadi kemungkinan besar pemberitaan yang diberikan tidak akan bertentangan dengan kebijakan politik sebuah organisasi 
yang berafiliasi dengan pemilik media. Republika.co.id yang berada dalam manajemen Republika dibeli oleh seorang konglomerat bernama Erick Thohir, sebagai bentuk partisipasinya dalam dunia pengembangan media Erick tidak terlalu berusaha mengendalikan Republika. Dalam system keredaksiannya. Sebagai contoh untuk membuat sebuah berita dan masuk dalam media cetak baik elektronik Republika mempercayakan pada keredaksian yang dmilikinya. Sebagai contoh, untuk memuat berita di situ ROL atau Republika cetak, keterlibatan pemilik media tidak terlalu terasa. Menurut Rahmat Santosa Basrah sebagai Kepala Cabang Republika Jawa Barat.” Isu yang dipandang penting ya kita naikkan, pemilik media hanya bicara tentang manajemen media, tidak terlibat langsung dalam penentuan isu dan teknis keredaksian”. (Dokumentasi Peneliti)

Level selanjutnya adalah level pengaruh luar organisasi media. (ekstramedia). Pada level ini terdapat pengaruh-pengaruh pada isi media yang berasal dari luar organisasi media itu sendiri. Pengaruhpengaruh dari media itu berasal dari sumber berita, pengiklan dan pembaca, kontrol pemerintah, pangsa pasar dan teknologi. Bisa dilihat bahwa Republika.co.id berusaha menjaga isu agra terlihat bahwa Islam bukanlah kelompok yang harus ditakuti atau membuat masalah.
Level terakhir dalam teori hierarki pengaruh ini adalah level ideologi. Ideologi diartikan sebagai kerangka berpikir tertentu yang dipakai oleh media untuk melihat realitas dan bagaiman mereka menghadapinya. Realitas disini yaitu kerusuhan Tanjung Balai Asahan. Berbeda dengan level sebelumya, level ini lebih bersifat abstrak. Ideologi ini menjadi acuan bagi wartawan dan redaktur dalam mengostruksikan suatu realitas yang kemudian dituliskan menjadi sebuah berita. Ideologi Republika.co.id merupakan ideology yang cenderung memihak Islam, karena berdasarkan pendirinya yaitu ICMI dan perkembangannya serta pemilihan isunya dapat dilihat keberpihakan Republika terhadap Islam.

Berita adalah produk dari konstruksi dan pemaknaan atas realitas. Pemaknaan seseorang atas suatu realitas bisa jadi berbeda dengan orang lain, yang tentunya menghasilkan "realitas" yang berbeda pula. Oleh karena itu, ukuran yang baku dan standar tidak bisa dipakai. Kalau ada perbedaan antara berita dengan realitas yang sebenarnya maka tidak dianggap sebagai kesalahan, tetapi memang seperti itulah pemaknaan mereka atas realitas. Di sini yang dipersoalkan bukan bias, seperti dalam pendekatan positivis (Eriyanto, 2012:31).

Pemberitaan mengenai Kerusuhan Tanjung Balai Asahan yang dimunculkan oleh media massa daring menjadi suatu 


\section{Vol. 2 No.1 Agustus 2017}

permasalahan dalam mengkonstruksi realitas sosial. Hal ini menjadi pembelajaran bagi media massa tersebut dalam memverifikasi data dan fakta yang ada secara komprehensif dan akurat. Kecepatan di media massa daring dapat berbanding lurus dengan keakuratan.

Dari pemberitaan tersebut pula dapat dilihat ada pihak yang disudutkan atau dirugikan baik dari sisi pro Islam atau tidak. Lewat berita-berita inilah terbangun pemahaman dan pemenuhan kebutuhan informasi masyarakat tentang isu yang jauh dari pantauan mereka. Jika mereka melihat bahwa keadaan sudah membaik maka Republika.co.id telah berhasil membuat khalayak meyakini dan memaknai realitas bahwa kerusuhan dan pembakaran vihara telah diselesaikan dengan baik.

Dari pemberitaan tentang kerusuhan Tnajung Balai Asahan ini peneliti lebih jauh lagi dapat melihat berate Republika.co.id sangat ingin menunjukkan ideology medianya, Menurut Eriyanto," ideologi juga berperan dalam proses produksi berita" Media berperan mendefinsisikan bagaimana realitas seharusnya dipahami, bagaimana realitas itu dijelaskan dengan cara tertentu kepada khalayak. Pendifinisian tersebut bukan hanya pada aspek peristiwa, melainkan juga aktoraktor sosial. Di antara berbagai fungsi media dalam mendefinisikan realitas, fungsi utama dalam pembahasan ideologi ialah media sebagai mekanisme integrasi sosial.
Oleh sebab itu dalam pembingkaian berita ini Republika.co.id menghadirkan berbagai tokoh yang berpengaruh di Negara ini agar terlihat mendukung tujuan pesan yang utama bagi Republika.co.id. Dalam hal ini, media berfungsi menjaga nilai-nilai kelompok dan mengontrol bagaimana nilai-nilai kelompok itu dijalankan. Untuk mengintegrasikan padangan masyarakat tersebut dalam nilai yang sama, media mendefinisikan nilai dan perilaku apa yang sesuai dengan nilai kelompok dan nilai apa yang dipandang menyimpang (Eriyanto, 2012: 144-145).

\section{KESIMPULAN}

Berdasarkan analisis di atas, peneliti menyimpulkan beberapa hal mengenai bingkai pemberitaan Kerusuhan Tanjung Balai Asahan pada Republika.co.id 30 Juli 2016. Simpulan ini sekaligus menjadi jawaban dalam tujuan penelitian, yakni mengetahui bagaimana Republika.co.id mendefinisikan masalah, memperkirakan penyebab masalah, membuat keputusan moral, dan menekankan penyelesaian masalah.

Menurut Republika.co.id kerusuhan Tanjung Balai Asahan berupa penjarahan dan pembakaran sudah mulai kondusif dan sudah terkendali serta masyarakat di lokasi kejadian telah tenang. Isu ini merupakan isu yang sudah menuju tahapan penyelesaian dan sudah terlihat titik temu penyelesaian masalah ini. Bukanlah hal rumit dan dampak dari 


\section{Vol. 2 No.1 Agustus 2017}

kerusuhan ini tidak terlalu besar. Penyebab masalah dalam isu ini menurut Republika.co.id yang melakukan pembingkaian adalah adanya warga non-muslim yang melakukan protes pada masjid karena volume suara azan. Dalam menentukan keputusan moral, Republika.co.id meberikan beberapa nilai moral yang diharapkan dipahami oleh masyarakat yakni "menahan diri, saling menghargai, tidak mudah terprovokasi, saling menghormati, dan toleransi”. Terhadap solusi dari permasalahan yang dibingkai oleh Republika.co.id solusi Hukum dan Komunikasi merupakan solusi yang ditawarkan. Semua perilaku yang masuk hukum pidana akan diproeses hukum dan diserahkan pada yang berwajib sementara terkait SARA, akan dilakukan musyawarah, diskusi serta konsolidasi antar elemen masyarakat dan pemuka agama di Tanjung Balai Asahan.

Analisa tersebut menunjukan keberpihakan Republika.co.id terhadap Islam dan ditemukan belum adanya sajian berita yang juga berisi pendapat dari perpektif lain baik itu dari kelompok non-muslim yang berada di lokasi kejadian atau oknum yang dirugikan dari kerusuhan dan pembakaran. Untuk menunjang agar berita yang dibangun itu komprehensif, hendaknya, Republika.co.id memilih narasumber dengan pandanganpandangan yang berbeda-beda.

\section{DAFTAR PUSTAKA}

Ardianto, Elvinaro, Lukiati Komala dan Siti Karlinah. 2009. Komunikasi Massa; Suatu Pengantar Edisi Revisi. Bandung: Simbiosa Rekatama Media.

Berger, Peter L. dan Thomas Luckmann. 1966.

Te Social Construction of Reality: A Treatise in the Sociology of Knowledge.

New York: Double Day \& Company, Inc.

Bungin, Burhan. 2009. Sosiologi

Komunikasi.Jakarta: Kencana Prenada Media Group

Eriyanto. 2009. Analisis Framing. Yogyakarta:

LKiS

Eriyanto. 2012. Analisis Framing; Konstruksi, Ideologi, dan Politik Media. Yogyakarta: LKIS; Edisi Khusus Komunitas

Latif, Yudi. 2013. Tuhan Pun Tidak Partisan. Bandung. Syabas Books.

Rakhmat, Jalaluddin. 2005. Psikologi

Komunikasi. Bandung: PT Remaja

Rosdakarya

Sobur, Alex. 2006. Analisis Teks Media Alex Sobur. Bandung: PT Remaja Rosdakarya.

Sugiyono. 2013. Metode Penelitian Kuatitatif,

Kualitatif, dan $R \& D . \quad$ Bandung:

Alfabeta.

Sumadiria, A.S. Haris. 2005. Junalistik Ondonesia: Menulis Berita dan Feature. Jakarta: Simbiosa Rekatama Medi 